\title{
Excess intravascular coagulation complicating low cardiac output
}

\author{
T. C. MCN. INGLiS, G. R. BREEZE, J. STUART, L. D. ABRAMS, K. D. ROBERTS, \\ AND S. P. SINGH
}

From the Department of Haematology and Heart Unit, The Children's Hospital, Birmingham

SYNOPSIS In 42 children with congenital heart disease coagulation factor levels were studied serially during the first 20 hours following cardiopulmonary bypass surgery. The acyanotic patients, and also cyanotic patients who survived the operation, showed a progressive improvement in their coagulation profile from initial low postoperative levels. In 12 cyanotic patients who died within 72 hours, however, the coagulation factor levels either remained low, or fell further, until death. Fresh frozen plasma was administered to eight of these patients without apparent benefit. The abnormal coagulation profile correlated significantly with low skin temperature and increased blood loss and was considered to represent excess intravascular coagulation secondary to low cardiac output and poor tissue perfusion.

Patients with congenital heart disease may show a coagulation defect either preoperatively or immediately following cardiopulmonary bypass. The preoperative defect may include thrombocytopenia (Hartmann, 1952), platelet function defects (Maurer, McCue, Caul, and Still, 1972; Ekert and Sheers, 1974), excess fibrinolysis (Gralnick, 1970), or disseminated intravascular coagulation (Dennis, Stewart, and Conrad, 1967; Komp and Sparrow, 1970). Recent studies have suggested that the basic defect in the preoperative cyanotic patient with tissue hypoxia and secondary polycythaemia is that of low-grade intravascular coagulation (Ihenacho, Breeze, Fletcher, and Stuart, 1973) with at least partial correction resulting from heparinization and/or venesection (Jackson, 1964; Dennis et al, 1967; Ihenacho et al, 1973; Wedemeyer and Lewis, 1973; Wedemeyer, Castaneda, Edson, and Krivit, 1973).

In the postoperative period the haemostatic defect is also reported to be multivaried and may again include thrombocytopenia, platelet function defects, excess fibrinolysis, or disseminated intravascular coagulation, plus the additional possibility of heparin rebound. There is uncertainty regarding the therapeutic value during this period of fresh frozen plasma, coagulation factor and platelet concentrates, fibrinolytic blockade with epsilon aminocaproic acid (EACA), or the reintroduction of systemic heparinization.

Received for publication 16 October 1974
A serial study has therefore been made in 42 children with congenital heart disease undergoing cardiopulmonary bypass to determine the nature of the postoperative haemostatic defect at different time intervals, to relate the coagulation abnormality to blood loss, urine output, and skin temperature, and to determine the predictive value of the preoperative and immediate postoperative coagulation profiles in relation to the subsequent development of a coagulation defect.

\section{Patients and Methods}

\section{PATIENTS}

Clinical details of the 42 children investigated from a total of 158 children undergoing cardiopulmonary bypass during the year of study are given in table $I$.

\begin{tabular}{|c|c|c|}
\hline & \multicolumn{2}{|c|}{ Congenital Heart Disease } \\
\hline & Acyanotic & Cyanotic \\
\hline $\begin{array}{l}\text { Number of patients } \\
\text { Age (years) } \\
\text { Mean } \\
\text { Range }\end{array}$ & $\begin{array}{l}18 \\
4 \cdot 8 \\
1-11 \cdot 5\end{array}$ & $\begin{array}{l}24 \\
3 \cdot 0 \\
0 \cdot 06-8 \cdot 9\end{array}$ \\
\hline $\begin{array}{l}\text { Cardiac lesion } \\
\text { VSD } \\
\text { ASD } \\
\text { Aortic stenosis } \\
\text { Transposition } \\
\text { Fallot's tetralogy } \\
\text { Other }\end{array}$ & $\begin{array}{r}10 \\
4 \\
2 \\
- \\
- \\
2\end{array}$ & $\begin{array}{r}- \\
- \\
10 \\
11 \\
3\end{array}$ \\
\hline
\end{tabular}

Table I Clinical details of the 42 children studied 
These patients were selected according to the week day allocated for operation although the selection was biased in favour of the more severely affected, cyanosed children. Twelve children, all with cyanotic congenital heart disease, died within 72 hours of the operation.

\section{SURGICAL PROCEDURE}

A midline sternotomy incision was made and the bypass circulation maintained by a Sarns roller pump using polyvinyl chloride tubing and a paediatric or infant Temptrol bubble oxygenator. A Sarns infant bubble trap or a $40 \mu$ Pall extracorporeal filter was incorporated in the circuit depending on the required flow rate. When hypothermia below $25^{\circ} \mathrm{C}$ was required an organ perfusion heat exchanger was used. In all but five cases the bypass circuit was primed with Hartmann's solution or $4.3 \%$ dextrose saline together with acid-citrate or citrate-phosphate-dextrose blood. Each unit of blood contained 1500 units of heparin, 20 m-equiv of sodium bicarbonate, and $3 \mathrm{ml}$ of $10 \%$ calcium chloride.

Systemic heparization was achieved with a dose of 300 units $/ \mathrm{kg}$ and corrected with approximately $4.5 \mathrm{mg} / \mathrm{kg}$ protamine sulphate given in divided doses.

Postoperative blood loss was measured as the output from the chest drainage tubes expressed as $\mathrm{ml} / \mathrm{m}^{2} /$ hour. Urine output was also recorded as $\mathrm{ml} / \mathrm{m}^{2} /$ hour. Skin temperature was recorded in 23 patients, using a surface applicator attached to the dorsum of the foot and connected to an electric thermometer (Light Laboratories), and expressed as the mean of all recordings up to 20 hours following operation, or until death if earlier.

\section{COAGULATION STUDIES}

Preanaesthetic venous blood was taken with minimal venous stasis using a 21-gauge butterfly needle. Subsequent samples were taken from an intraarterial polythene cannula which was inserted following induction of anaesthesia to record arterial pressure. Considerable care was taken to avoid heparin contamination of the cannula samples, the first $5 \mathrm{ml}$ of blood being discarded.

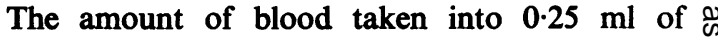
$3.8 \%$ sodium citrate for coagulation studies was adjusted in proportion to elevated packed cell volume (PCV) according to the formula:

Volume of blood added (ml)

$$
=2.25 \times \frac{100-45}{100 \text {-patient's PCV }}
$$

Blood for fibrinogen was taken into aprotinin-citrate, for platelet count and PCV into dried EDTA, and for fibrin degradation products (FDP) into aprotinin in a dry container. The citrate-anticoagulated specimens were kept on melting ice during transfer to the laboratory and centrifuged immediately at $1000 \mathrm{~g}$ for $10 \mathrm{~min}$ at $0-4^{\circ} \mathrm{C}$. Plasma for estimation of factors $V$ and VIII, fibrinogen and plasminogen, and serum for FDP estimation were stored at $-20^{\circ} \mathrm{C}$ and all samples from the same patient subsequently assayed in one batch.

The following methods were used: PCV by a microhaematrocrit method and platelets by phasecontrast microscopy (Dacie and Lewis, 1968), factors V and VIII by one-stage assays after adsorption with aluminium hydroxide (Biggs and Macfarlane, 1966; Hardisty and Ingram, 1965), fibrinogen by the method of Ellis and Stransky (1961), plasminogen by the method of Remmert and Cohen (1949) as modified by Alkjaersig, Fletcher, and Sherry (1959), euglobulin lysis time (ELT) by the method of Cash and Allan (1967), and serum FDP by the method of Merskey, Kleiner, and Johnson (1966) as modified by Das, Allan, Woodfield, and

\begin{tabular}{|c|c|c|c|}
\hline & $\begin{array}{l}\text { Preanaesthetic } \\
\text { Venous Blood }\end{array}$ & $\begin{array}{l}\text { Postanaesthetic } \\
\text { Arterial Blood }\end{array}$ & $\begin{array}{l}\text { Significance of Difference of } \\
\text { Means (P) }\end{array}$ \\
\hline $\begin{array}{l}\text { Fibrinogen } \\
\quad(\mathbf{g} 1)\end{array}$ & $\begin{array}{r}2.21 \\
\pm \quad 0.45 \\
(8)\end{array}$ & $\begin{array}{r}1.98 \\
\pm \quad 0.28 \\
(8)\end{array}$ & $>0.1$ \\
\hline Factor V (\%) & $\begin{array}{r}102.0 \\
\pm \quad 14 \cdot 3 \\
\quad(11)\end{array}$ & $\begin{array}{r}110.9 \\
\pm \quad 38.9 \\
(11)\end{array}$ & $>0.1$ \\
\hline Factor VIII (\%) & $\begin{array}{r}146.0 \\
\pm \quad 62.7 \\
(11)\end{array}$ & $\begin{array}{r}138 \cdot 8 \\
\pm \quad 64 \cdot 5 \\
(11)\end{array}$ & $>0 \cdot \mathbf{i}$ \\
\hline Plasminogen (casein units) & $\begin{array}{r}2.70 \\
\pm \quad 0.79 \\
(10)\end{array}$ & $\begin{array}{r}2.62 \\
+\quad \begin{array}{l}0.61 \\
(10)\end{array}\end{array}$ & $>0.1$ \\
\hline
\end{tabular}

Table II Comparison of mean values $\pm S D$ between preanaesthetic venous blood and arterial blood taken immediately after induction of anaesthesia

Number of patients studied in parentheses. 
Cash (1967) and using fibrinogen-sensitized sheep erythrocytes (Wellcome Research Laboratories). Other tests were performed using standard methods.

A protamine sulphate titration was performed on each postoperative blood sample showing a prolonged thrombin clotting time. The appropriate amount of protamine was added to achieve correction before coagulation assays were performed if there was evidence of residual heparin in the sample.

\section{STATISTICAL METHODS}

The significance between mean values was assessed using the $t$ test while correlation between variables was determined by linear regression and correlation coefficient.

\section{Results}

PREOPERATIVE COAGULATION PROFILE

There was no significant difference (table II) between preanaesthetic venous specimens and arterial specimens taken immediately after induction of anaesthesia for mean levels of fibrinogen, factors $V$ and VIII, and plasminogen. The preoperative coagulation results for the 42 patients, obtained from blood samples taken either before or immediately after induction of anaesthesia, are shown in figures 1-6. The patients have been subdivided into three main groups: 18 acyanotic patients, 12 cyanotic patients who survived, and 12 cyanotic patients who died.

\section{POSTOPERATIVE COAGULATION PROFILE}

Arterial blood samples were taken immediately postoperatively (defined as the time of transfer to intensive care) and thereafter at intervals up to 20 , and sometimes 60 , hours. The results obtained immediately postoperatively and at two, four, and 20 hours provided a coagulation profile which is shown in figs 1-6 for the three main patient groups.

Statistically significant differences were found between the mean values for the three patient groups at different postoperative times. When cyanotic patients who survived were compared with acyanotic patients, the coagulation profile for the former showed a significant reduction only in the immediate postoperative factor VIII level. Although the platelet count was significantly lower in cyanotic patients preoperatively there was no significant difference postoperatively.

Cyanotic patients who subsequently died, when compared with cyanotic patients who survived, showed a significantly lower platelet count at each postoperative time interval with the exception of the four-hour sample. The mean fibrinogen level was also significantly lower at each interval and the factor $\mathrm{V}$ level was significantly lower at four hours and 20 hours. Serum FDP levels were higher in the cyanotic patients who subsequently died but there was a wide standard deviation and the differences between means did not achieve statistical significance until 20 hours. Factor VIII and plasminogen levels were not significantly different at any stage.

Seven of the 12 cyanotic patients who died showed a combination of low skin temperature, low urine output, excessive bleeding, low coagulation factor levels, and raised serum FDP suggesting the complication of disseminated intravascular coagulation. The individual coagulation results obtained from the final blood sample obtained before death are given for these 12 patients in table III. Seven of the patients showed three or more coagulation results outside the extremes of the range obtained for cyanotic patients who survived.

\begin{tabular}{|c|c|c|c|c|c|c|c|c|}
\hline $\begin{array}{l}\text { Time of Death } \\
\text { (h postoperatively) }\end{array}$ & $\begin{array}{l}\text { Mean Skin } \\
\text { Temperature } \\
\left({ }^{\circ} \mathrm{C}\right)\end{array}$ & $\begin{array}{l}\text { Blood Loss } \\
\left(\mathrm{ml} / \mathrm{m}^{2} / \text { hour }\right)\end{array}$ & $\begin{array}{l}\text { Platelets } \\
\left(\times 10^{\circ} / l\right)\end{array}$ & $\begin{array}{l}\text { Fibrinogen } \\
(g / l)\end{array}$ & $\begin{array}{l}V \\
(\%)\end{array}$ & $\begin{array}{l}V I I I \\
(\%)\end{array}$ & $\begin{array}{l}\text { Plasminogen } \\
\text { (casein units) }\end{array}$ & $\begin{array}{l}F D P \\
(\mu g / m l)\end{array}$ \\
\hline $\begin{array}{r}6 \\
30 \\
20 \\
30 \\
20 \\
9 \\
12 \\
20 \\
1 \\
63 \\
20 \\
50\end{array}$ & $\begin{array}{r}- \\
- \\
-\bar{z} \\
27 \cdot 5 \\
29 \cdot 8 \\
-\overline{0} \\
28 \cdot 0 \\
29 \cdot 0 \\
31 \cdot 0 \\
28 \cdot 0 \\
29 \cdot 5 \\
29 \cdot 0\end{array}$ & $\begin{array}{r}100 \cdot 5 \\
25 \cdot 7 \\
42 \cdot 0 \\
30 \cdot 0 \\
35 \cdot 4 \\
25 \cdot 9 \\
83 \cdot 3 \\
107 \cdot 8 \\
- \\
23 \cdot 4 \\
79 \cdot 7 \\
50 \cdot 0\end{array}$ & $\begin{array}{r}75 \\
25 \\
159 \\
75 \\
50 \\
55 \\
83 \\
24 \\
40 \\
39 \\
119 \\
40\end{array}$ & $\begin{array}{r}94 \\
94 \\
164 \\
307 \\
212 \\
206 \\
130 \\
100 \\
140 \\
280 \\
135 \\
120\end{array}$ & $\begin{array}{r}30 \\
14 \\
90 \\
40 \\
8 \\
35 \\
17 \\
9 \\
24 \\
12 \\
46 \\
22\end{array}$ & $\begin{array}{r}17 \\
140 \\
81 \\
90 \\
42 \\
50 \\
200 \\
42 \\
47 \\
115 \\
52 \\
60\end{array}$ & $\begin{array}{l}0.6 \\
0.4 \\
1.8 \\
2.5 \\
1.9 \\
1.7 \\
0.8 \\
1.9 \\
2.4 \\
1.3 \\
1.7 \\
0.7\end{array}$ & $\begin{array}{r}160 \\
40 \\
20 \\
10 \\
40 \\
80 \\
13 \\
20 \\
10 \\
40 \\
10 \\
80\end{array}$ \\
\hline
\end{tabular}

Table III Coagulation values obtained from the final blood sample before death in the 12 cyanotic patients dying within 72 hours

1The values in bold type represent levels below the lowest value obtained at the equivalent time interval for the 12 cyanotic patients who survived. Those in bold type for FDP and blood loss values are higher than the upper limit of the range for cyanotic patients who survived. 

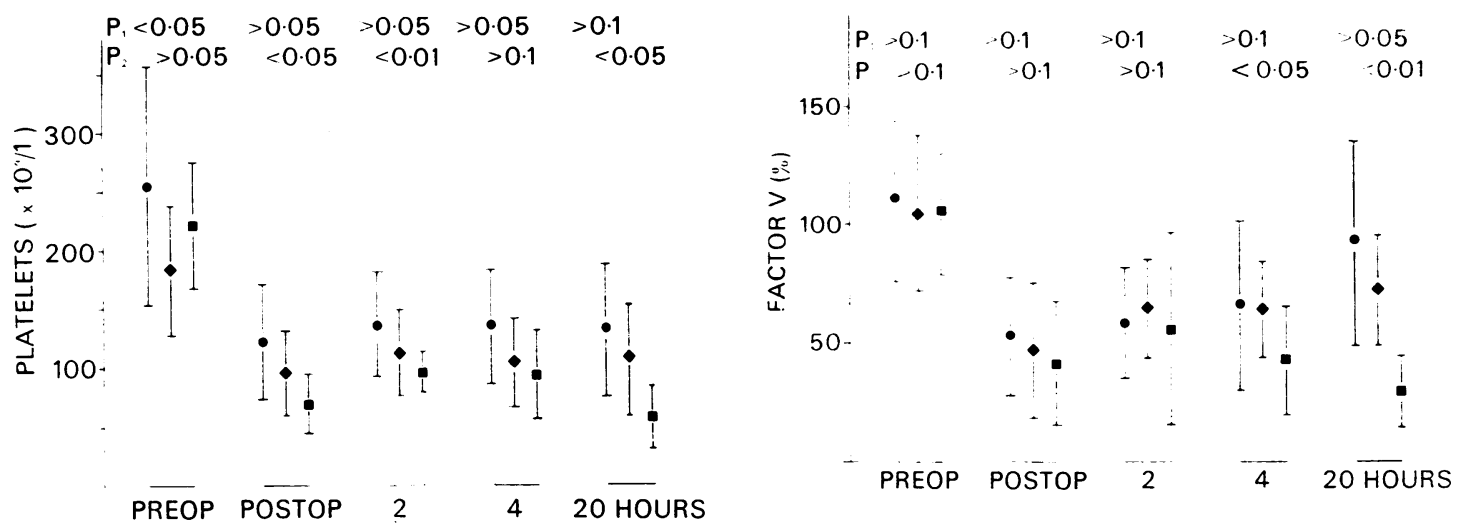

Fig 1

Fig 4

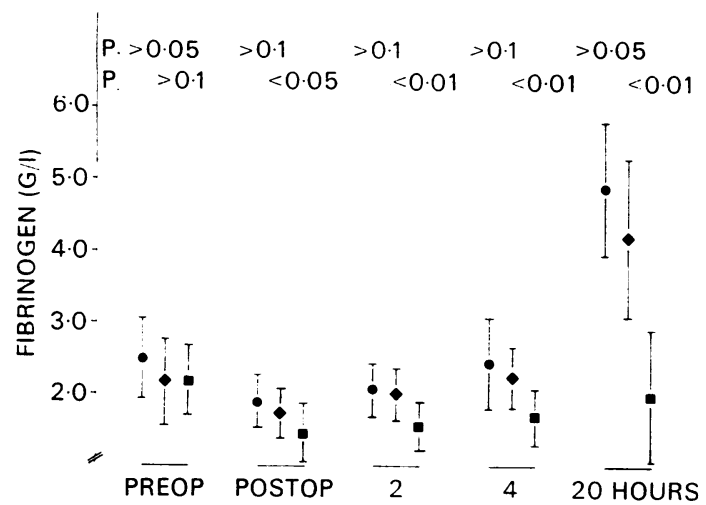

$$
\left\{\begin{array}{lrrrr}
P .>0.1 & >0.1 & >0.05 & >0.1 & >0.05 \\
P .>0.1 & >0.1 & >0.05 & >0.1 & <0.05
\end{array}\right.
$$

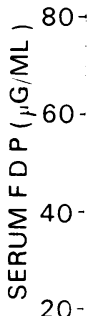

Fig 2

Fig 5

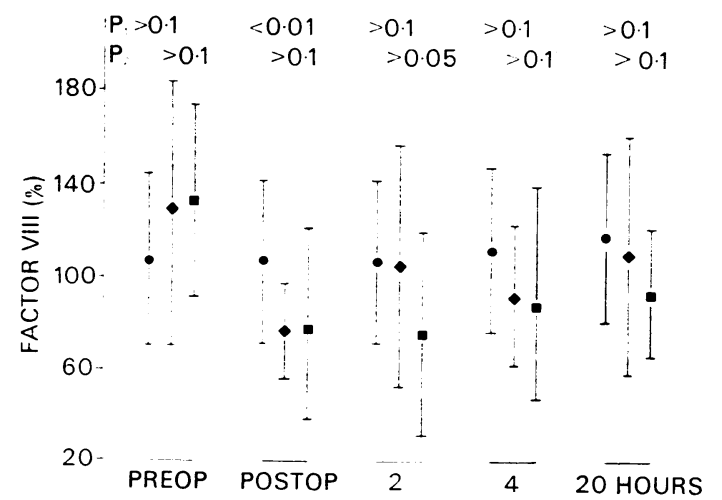

Fig 3

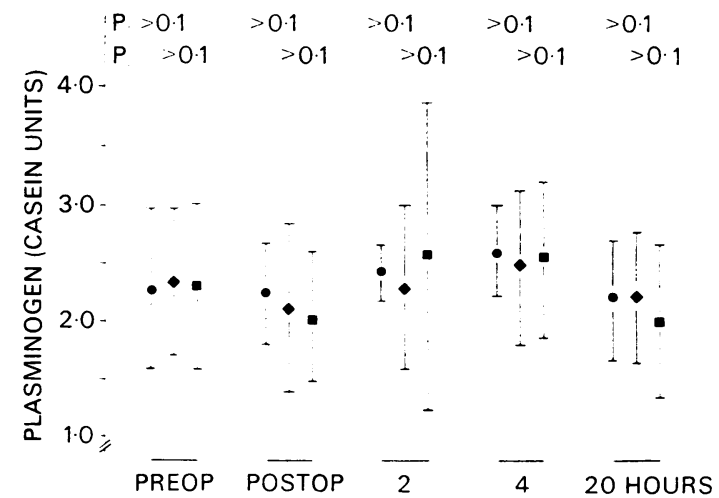

Fig 6

Figs 1-6 Coagulation profiles showing mean values $\pm 1 S D$ obtained preoperatively, immediately postoperatively and at two, four, and 20 hours thereafter. $P_{1}$ represents significance of difference between mean values for acyanotic patients $(\bigcirc)$ and cyanotic patients who survived $(\diamond)$ and $P_{2}$ significance of difference between cyanotic patients who survived $(\diamond)$ and who died $(\square)$. 
PREDICTIVE VALUE OF COAGULATION PROFILE The preoperative coagulation factor mean levels were not significantly different between cyanotic patients who subsequently died and those who survived. Cyanotic patients who subsequently died did show significantly lower mean platelet and fibrinogen levels immediately postoperatively but the range of values was so wide that it was impossible to predict the outcome in individual patients.

\section{CORRELATIONS WITH BLOOD LOSS, URINE}

OUTPUT, AND SKIN TEMPERATURE

The mean values for postoperative blood loss, urine output, and skin temperature up to 20 hours or death were compared in the three main patient groups (fig 7). Cyanotic patients who died showed significantly greater blood loss, lower urine output, and lower skin temperature than cyanotic patients who survived.

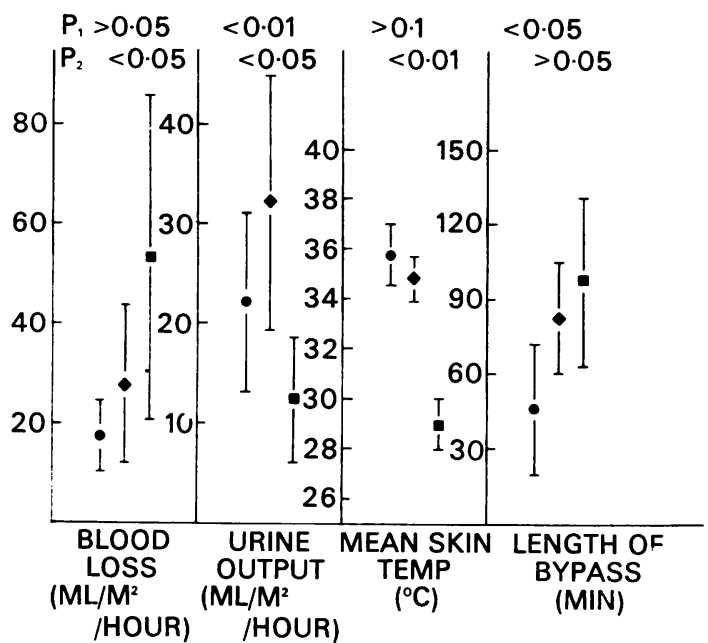

Fig 7 Comparison of mean values $\pm 1 S D$ for blood loss, urine output, skin temperature, and duration of bypass in the three patient groups. Symbols as in figures 1-6.

Blood loss correlated significantly with level of thrombocytopenia $(r=0.35, P<0.05)$, degree of hypofibrinogenaemia $(r=0.63, P<0.05)$ and increase of FDP $(r=0.45, P<0.01)$ at both two hours and 20 hours postoperatively and also with fall in factor $\mathrm{V}$ level $(\mathrm{r}=0.44, \mathrm{P}<0.01)$ at 20 hours. There was no correlation with factor VIII at any stage.

The mean skin temperature was found to correlate significantly with the 20-hour (or nearest time interval to death) coagulation factor levels for platelets $(\mathrm{r}=0.55, \mathrm{P}<0.01)$ and factor $\mathrm{V}(\mathrm{r}=0.89, \mathrm{P}<0.01)$ and inversely with rise in FDP $(r=0.55, \mathrm{P}<0.01)$. There was no correlation with the levels of factor VIII or fibrinogen. The mean skin temperature for individual patients was $31^{\circ} \mathrm{C}$ or lower in each of the patients who died and above $32.8^{\circ} \mathrm{C}$ in each of the survivors.

EFFECT OF LENGTH OF BYPASS

The duration of bypass (including both perfusion time and the period of circulatory arrest) was significantly longer in cyanotic compared with acyanotic patients (fig 7) but was not significantly different between cyanotic patients who lived or died. The duration of bypass correlated significantly $(r=0.47, P<0.01)$ with the percentage fall in factor VIII between the preoperative and immediate postoperative values; there was no significant correlation $(P>0.05)$ with fall in platelet count, factor $\mathrm{V}$ or fibrinogen, or rise in serum fibrinogen degradation products.

\section{FIBRINOLYTIC STUDIES}

The mean values for ELT in the three main patient groups were not significantly different before operation. Following bypass the ELT became prolonged, usually to greater than $200 \mathrm{~min}$, in all patients and there was therefore no evidence of increased fibrinolysis.

\section{EFFECT OF FRESH FROZEN PLASMA}

Eight cyanotic patients were given fresh frozen plasma in a dose of approximately $20 \mathrm{ml} / \mathrm{kg}$ over the first two postoperative hours. These patients were not randomly selected and tended to be patients with above average postoperative blood loss.

The mean percentage increases in fibrinogen and factor $V$ and VIII levels over the first two postoperative hours were not significantly greater than in eight cyanotic patients, matched retro-

\begin{tabular}{|c|c|c|c|}
\hline & $\begin{array}{l}\text { Patients Given } \\
\text { FFP }(n=8)\end{array}$ & $\begin{array}{l}\text { No FFP } \\
(n=8)\end{array}$ & $\begin{array}{l}\text { Significance of } \\
\text { Difference of } \\
\text { Means (P) }\end{array}$ \\
\hline Fibrinogen ( $\%$ rise) & $\begin{array}{r}17 \cdot 3 \\
\pm 21 \cdot 4\end{array}$ & $\begin{array}{r}0.6 \\
\pm 21.8\end{array}$ & $>0.1$ \\
\hline Factor V ( $\%$ rise) & $\begin{array}{r}37.6 \\
>53.6\end{array}$ & $\begin{array}{r}78.5 \\
\pm 90.6\end{array}$ & $\pm 0 \cdot 1$ \\
\hline Factor VIII ( $\%$ rise) & $\begin{array}{r}20.5 \\
\pm 40.6\end{array}$ & $\begin{array}{r}10.6 \\
>45.6\end{array}$ & $>0.1$ \\
\hline $\begin{array}{l}\text { Blood loss } \\
\text { ( } \mathrm{ml} / \mathrm{m}^{2} / \text { hour) }\end{array}$ & $\begin{array}{r}60.8 \\
\pm 28.6\end{array}$ & $\begin{array}{r}37 \cdot 7 \\
\pm 28 \cdot 4\end{array}$ & $>0.1$ \\
\hline
\end{tabular}

Table IV Effect of FFP on the mean $( \pm S D)$ percentage rise in coagulation factor levels between the immediate postoperative and the two-hour values 
spectively for type of operation and survival, who were not given fresh frozen plasma (table IV). There was no significant difference in blood loss between the two groups.

\section{HEPARIN REBOUND}

Eight of the 24 cyanotic patients developed excessive bleeding within two hours of transfer to intensive care and were shown to have excess circulating heparin by means of thrombin and reptilase clotting times and protamine sulphate titration; this excess was corrected with protamine sulphate. All eight patients had previously been rendered hypothermic $\left(12-32^{\circ} \mathrm{C}\right)$ during the operation. Only one of these eight patients subsequently developed features of disseminated intravascular coagulation.

\section{Discussion}

Despite numerous studies of the haemostatic defect following cardiopulmonary bypass there is still uncertainty over the interpretation and management of the various defects which have been reported. The vogue for prophylactic fibrinolytic blockade with EACA has passed (Porter and Silver, 1968) but there is uncertainty over the potential value of coagulation factor and platelet concentrates and of heparin.

A coagulation profile performed serially during and after bypass has previously been used to study the haemostatic defect (Porter and Silver, 1968; Douglas, McNicol, Bain, and Mackey, 1966; Thurnherr, 1967; Gralnick and Fischer, 1971). These profiles have been performed on heterogeneous groups of patients comprising congenital and acquired heart defects, children and adults, and cyanotic and acyanotic patients. In contrast the profile obtained in the present study was confined to children with congenital defects and has revealed quantitative differences between three patient subgroups.

Previous studies have shown that the normal response following cessation of bypass is an initial fall in coagulation factor levels followed by a progressive return towards preoperative values. Factor VIII levels show minor changes only (Gralnick and Fischer, 1971) while fibrinogen shows a small reduction (Gralnick and Fischer, 1971) followed by rapid correction (Thurnherr, 1967; Porter and Silver, 1968) and a subsequent rebound to supranormal levels (Thurnherr, 1967; Porter and Silver, 1968; Boyd, Engelman, Beaudet, and Lackner, 1972). Factor V levels fall further, and are still reduced by $30 \%$ in the first few postoperative hours (Douglas et al, 1966; Thurnherr, 1967; Porter and Silver, 1968; Gralnick and Fischer,
1971), but only occasionally fall to a level which may contribute to excessive bleeding (Gralnick and Fischer, 1971). The increased fibrinolytic activity associated with bypass also corrects spontaneously within a few hours (Thurnherr, 1967; Porter and Silver, 1968; Gralnick and Fischer, 1971) unless there is a defect in the bypass technique (Brooks and Bahnson, 1972). The present study showed a similar pattern to these previous reports in both the cyanotic and acyanotic patients who survived.

The cyanotic patients who survived, when compared with acyanotic patients, showed a significant reduction in factor VIII level only and this was related to the duration of bypass. The cyanotic patients who subsequently died, however, showed significantly lower mean levels for platelets, fibrinogen, and factor $V$ than the cyanotic patients who survived. They also showed higher serum FDP levels, but the differences between mean FDP values did not reach statistical significance until 20 hours postoperatively. The cyanotic patients who survived showed FDP values ranging from normal up to $40 \mu \mathrm{g} / \mathrm{ml}$. Four of the 12 cyanotic patients who died showed FDP values of 80 to $160 \mu \mathrm{g} / \mathrm{ml}$; this was present as early as two hours postoperatively in three patients who died four hours, seven hours and 28 hours later. In a previous study (Boyd et al, 1972) an upper FDP limit of $5.6 \mu \mathrm{g} / \mathrm{ml}$ was found in uncomplicated bypass compared with values of $11.2 \mu \mathrm{g} / \mathrm{ml}$ or above in all of 10 patients who developed disseminated intravascular coagulation. The 10 patients, however, showed late onset disseminated intravascular coagulation (five days on average) following valve replacement and by this time FDP levels in uncomplicated patients have largely returned to preoperative values.

The more severe coagulation defect in the 12 cyanotic patients who died, and in particular in seven of them, was suggestive of disseminated intravascular coagulation. The results obtained in the first two postoperative hours for individual cyanotic patients were not predictive of subsequent death or disseminated intravascular coagulation, with the possible exception of FDP levels of $80 \mu \mathrm{g} / \mathrm{ml}$ or above. Thereafter the coagulation factor levels in the patients who died either remained low or fell further until death, in contrast to the rebound towards normal levels in the survivors. The duration of bypass was not significantly longer in cyanotic patients who died. The deterioration in their coagulation profile with time and the associations with low skin temperature and low urine output suggest instead that this is an acquired defect secondary to the hypoxia of poor tissue perfusion resulting from low cardiac output.

Clearly, the ideal form of treatment of the coagu- 
lation defect associated with low cardiac output is correction of the perfusion defect by, for example, the use of catecholamines or possibly a further period of support with extracorporeal circulation. The coagulation abnormality is a secondary phenomenon and its management with replacement therapy or systemic heparinization should also be considered as such. It is unknown whether the fibrin deposition of disseminated intravascular coagulation contributes significantly to the poor tissue perfusion of a low cardiac output state following bypass and it is uncertain whether the infusion of coagulation factors will be beneficial or harmful in that fibrin deposition may be exacerbated. Eight patients in the present study were given FFP in a non-randomized preliminary study; there was no significantly greater rise in levels of fibrinogen, factor V, and factor VIII compared with a control group. Coagulation factor concentrates are therefore probably necessary to achieve any significant rise in factor levels. Heparinization has been shown to have a beneficial effect in disseminated intravascular coagulation presenting some five days postoperatively (Boyd et al, 1972) but the risks of haemorrhage are obvious if large doses of heparin are administered earlier.

Randomized controlled trials of replacement therapy with coagulation factor and platelet concentrates, with and without heparinization, would therefore seem necessary to determine how best to correct the coagulation defect. Patients may be selected for this type of study by performing a coagulation profile serially whenever persistently low postoperative skin temperatures are recorded, but any form of trial will be extremely difficult to perform and evaluate against the changing background of blood loss, blood transfusion, and other forms of supportive therapy. It would seem more profitable to concentrate on measures directed primarily against the underlying defect in tissue perfusion.

This study suggests that any patient who shows poor tissue perfusion with persistently low skin temperature four to 20 hours postoperatively, with or without excess haemorrhage, is likely to develop disseminated intravascular coagulation. In contrast, if a patient bleeds excessively within the first four postoperative hours then a more likely cause is heparin rebound, a specific bleeding site, or thrombocytopenia.

We are indebted to the Children's Hospital Centenary Research Fund for financial support. Reprint requests to JS.
References

Alkjaersig, N., Fletcher, A. P., and Sherry, S. (1959). The mechanism of clot dissolution by plasmin. J. clin. Invest., 38, 1086-1095.

Biggs, R., and Macfarlane, R. G. (1966). Treatment of Haemophilia and Other Coagulation Disorders, pp. 368-369. Blackwell, Oxford.

Boyd, A. D., Engelman, R. M., Beaudet, R. L., and Lackner, H. (1972). Disseminated intravascular coagulation following extracorporeal circulation. J. thorac. cardiovasc. Surg., 64, 685-693.

Brooks, D. H., and Bahnson, H. T. (1972). An outbreak of hemorrhage following cardiopulmonary bypass. J. thorac. cardiovasc. Surg., 63, 449-452.

Cash, J. D., and Allan, A. G. E. (1967). Effect of mental stress on the fibrinolytic reactivity to exercise. Brit. med. J., 2, 545-548.

Dacie, J. V., and Lewis, S. M. (1968). Practical Haematology, 4th ed., p. 70 . Churchill, London.

Das, P. C., Allan, A. G. E., Woodfield, D. G., and Cash, J. D. (1967). Fibrin degradation products in sera of normal subjects. Brit. med. J., 4, 718-720.

Dennis, L. H., Stewart, J. L., and Conrad, M. E. (1967). Heparin treatment of haemorrhagic diathesis in cyanotic congenital heart disease. Lancet, 1, 1088-1089.

Douglas, A. S., McNicol, G. P., Bain, W. H., and Mackey, W. A. (1966). The haemostatic defect following extracorporeal circulation. Brit. J. Surg., 53, 455-467.

Ekert, H., and Sheers, M. (1974). Preoperative and postoperative platelet function in cyanotic congenital heart disease. $J$. thorac. cardiovasc. Surg., 67, 184-190.

Ellis, B. C., and Stransky, A. (1961). A quick and accurate method for the determination of fibrinogen in plasma. J. Lab. clin. Med. 58, 477-488.

Gralnick, H. R. (1970). 6-aminocaproic acid in preoperative correction of haemostatic defect in cyanotic congenital heartdisease. Lancet, 1, 1204-1205.

Gralnick, H. R., and Fischer, R. D. (1971). The hemostatic response to open-heart operations. J. thorac. cardiovasc. Surg., 61, 909. 915.

Hardisty, R. M., and Ingram, G. I. C. (1965). Bleeding Disorders: Investigation and Management, pp. 304-306. Blackwell, Oxford.

Hartmann, R. C. (1952). A hemorrhagic disorder occurring in patients with cyanotic congenital heart disease. Bull. Johns Hopk. Hosp., 91, 49-67.

Ihenaco, H. N. C., Breeze, G. R., Fletcher, D. J., and Stuart, J. (1973), Consumption coagulopathy in congenital heart-disease. Lancet, 1, 231-234.

Jackson, D. P. (1964). Hemorrhagic diathesis in patients with cyanotic congenital heart disease: preoperative management. Ann. N.Y. Acad. Sci., 115, 235-251.

Komp, D. M., and Sparrow, A. W. (1970). Polycythemia in cyanotic heart disease-a study of altered coagulation. J. Pediat., 76, 231-236.

Maurer, H. M., McCue, C. M., Caul, J., and Still, W. J. S. (1972). Impairment in platelet aggregation in congenital heart disease. Blood, 40, 207-216.

Merskey, C., Kleiner, G. J., and Johnson, A. J. (1966). Quantitative estimation of split products of fibrinogen in human serum, relation to diagnosis and treatment. Blood, 28, 1-18.

Porter, J. M., and Silver, D. (1968). Alterations in fibrinolysis and coagulation associated with cardiopulmonary bypass. J. thorac. cardiovasc. Surg., 56, 869-878.

Remmert, L. F., and Cohen, P. P. (1949). Partial purification and properties of a proteolytic enzyme of human serum. J. biol. Chem., 181, 431-448.

Thurnherr, N. (1967). Blood coagulation studies and extracorporeal circulation in man. Thromb. Diathes. haemorrh. (Stuttg.), 18, 634-646.

Wedemeyer, A. L., Castaneda, A. R., Edson, J. R., and Krivit, W. (1973). Serial coagulation studies in patients undergoing Mustard procedure. Ann. Thorac. Surg., 15, 120-127.

Wedemeyer, A. L., and Lewis, J. H. (1973). Improvement in hemostasis following phlebotomy in cyanotic patients with heart disease. J. Pediat., 83, 46-50. 